\title{
POLLUTION ASSESSMENT IN URBAN AREAS USING AIR POLLUTION TOLERANCE INDEX OF TREE SPECIES
}

\author{
VANDA ÉVA MOLNÁR ${ }^{1}$, BÉLA TÓTHMÉRÉSZ ${ }^{2}$, SZILÁRD SZABÓ ${ }^{1} \&$ EDINA SIMON $^{3}$ \\ ${ }^{1}$ University of Debrecen, Department of Physical Geography and Geoinformatics, Hungary \\ ${ }^{2}$ MTA-DE Biodiversity and Ecosystem Services Research Group, Hungary \\ ${ }^{3}$ Department of Ecology, University of Debrecen, Hungary
}

\begin{abstract}
Air pollution has a large impact on the biochemical and morphological parameters of plants, and also decreases their growth and overall health. Therefore, biomonitoring is a reliable and cost-effective method to assess air quality. The tolerance of plant species can be assessed with the use of Air Pollution Tolerance Index (APTI), which is calculated from ascorbic acid content, relative water content, leaf extract $\mathrm{pH}$, and total leaf chlorophyll content of tree leaves. In this study, we reviewed published studies from several countries around the world about APTI. Performance of APTI was also evaluated comparing industrial, roadside and urban areas. In our work, APTI of Tilia sp. and Celtis occidentalis were used and evaluated in Debrecen city, Hungary. Leaf samples were collected from 12 areas in the city. Similar to earlier studies, ascorbic acid content was determined by titration with iodine solution. Chlorophyll was extracted from leaf samples with ethanol, and it was measured using spectrophotometric analysis. Relative water content was measured by the weight method. Comparison of selected studies showed that China and India are the most polluted countries and they had plant species with the highest APTI values. Lowest APTI was reported from Iran which is one of most airpolluted regions in the world. In Hungary, APTI was moderate compared to other countries. The tolerance of plant species at different study sites decreased in the following order: industrial $>$ roadside $>$ urban areas. This suggests the best conditions for sensitive species' development and growth in urban areas, while the presence of industrial activities in certain areas demands higher tolerance from plants. Keywords: ascorbic acid, biomonitoring, leaf extract $\mathrm{pH}$, relative water content, total leaf chlorophyll, tree leaves.
\end{abstract}

\section{INTRODUCTION}

Nowadays, environmental pollution is a well-recognized and serious problem of our society on the global scale. In most of the modern cities, industrialization and urbanization cause increasing air pollution. In an urban environment the largest contributor to air pollution is the emission from vehicular traffic. Traffic related pollution consist of exhaust and also nonexhaust emissions. The latter includes brake, tire, clutch and road surface wear as well as resuspension of previously deposited dust and soil dust [1]. The impact of industries on the vegetation is reported by several earlier studies [2]-[5]. Dust emission is one of the main form of pollution from both vehicular traffic and industrial activities. Naturally, suspended particulate matter show seasonal and even daily variations in quality and quantity depending on weather conditions like temperature, humidity, and rain [6]. Deposition speed of suspended particles is influenced by their shape and size, which determine the mechanisms of sedimentation, diffusion, impaction, and precipitation [7].

Plants, especially trees act as living filters in polluted areas. Tree leaves multiply the ground area of a single tree, resulting in a rather large surface area for the accumulation of pollutants. Pollutant capturing capacity varies among species, and it is determined by leaf surface geometry, foliage characteristics and tree height. Aside from adsorption of dust on the leaf surface, finer pollutants are also absorbed and accumulated inside the leaf tissue through stomatal pores [6]. Tree leaves are continuously exposed to the atmosphere. Thus, air quality is apparently reflected on the plant health through morphological and biochemical 
changes [8]. Therefore, biomonitoring of plants is a useful tool to assess the impact of pollutants released into the atmosphere. Roadside vegetation and flora around factories, power plants and industrial sites are the most common subjects of researches carried out in the field of biomonitoring.

Stress caused by air pollutants can affect the number of leaves, flowers and fruits, leaf area, length of stem and roots, germination of seeds, photosynthetic pigments, relative water content, leaf extract $\mathrm{pH}$, ascorbic acid etc. [7], [9]. Primary productivity of plants, growth and development of biomass depend on chlorophyll content, which is greatly affected by pollution load [10]. Loss of chlorophyll content in plants is a common indication of degraded air quality; however, tolerant species can even have enhanced chlorophyll content at polluted sites as a defence mechanism under stressful conditions. Thus, higher chlorophyll content overall favours tolerance. Relative water content (RWC) is the momentary water in the leaves relative to their full turgidity. Higher RWC also improves plants' tolerance, as it helps maintaining physiological balance under stress condition through increased transpiration rates. Leaf extract $\mathrm{pH}$ influences stomatal permeability of air pollutants. It is reported that acidic compounds in the atmosphere reduce the leaf $\mathrm{pH}$ [11]. The more sensitive a certain species is, the more drastic the rate of this reduction is [12]. Generally, plants with leaf $\mathrm{pH}$ value maintained around 7 are considered to be tolerant, as acidic $\mathrm{pH}$ conditions greatly hinder photosynthetic activity [10]. Ascorbic acid or vitamin $\mathrm{C}$ is a natural antioxidant, which is essential for several physiological mechanisms and also protects from oxidative, pollution related compounds. Consistently, higher ascorbic acid content in plant tissue indicates higher pollution tolerance.

Air Pollution Tolerance Index (APTI) became a common and useful method for evaluating the sensitivity of species against pollution. It is calculated from total chlorophyll content, relative water content, leaf extract $\mathrm{pH}$ and ascorbic acid content. Higher APTI value means that the plant species is more tolerant to pollution, and therefore it can be planted at polluted sites for improvement of air quality. Sensitive species, on the other hand, are expected to have low values of APTI, and they can be used as indicators of pollution present in the environment. In this work, we reviewed studies from several countries around the world about APTI of plants in urban and industrial areas, and along roadsides, and compared the data with the findings of our research in Hungary.

\section{METHODOLOGY}

\subsection{Data collection of earlier studies}

We collected articles about APTI from several countries around the world to compare their findings. The number of articles found suitable for this purpose was relatively low, and it was further reduced by some restrictions. For example, there are regions where the local vegetation mostly consists of herbaceous plants, and in some cases only ornamental [13] or climber plants [14] were studied. To improve urban air quality trees or larger shrubs perform best as pollution sinks due to their total foliage surface. In this aspect, herbs might be less relevant. In this paper, we assessed the tolerance of tree, so data about herbs and minor shrubs were excluded from our comparisons. Most of the data was from India [6]-[8], [10], [14][21], and from a few other Asian and African countries, such as Iran [12], China [11], [22], Indonesia [23] and Nigeria [24]. The selected studies are listed in Table 1 along with a short description of each study area. 
Table 1: Description of areas of earlier studies.

\begin{tabular}{llll}
\hline References & Country & Study area & Site description \\
\hline $\begin{array}{l}\text { Liu and Ding 2008 } \\
\text { [22] }\end{array}$ & China & industrial & Near a Beijing steel factory. \\
$\begin{array}{l}\text { Molnár et al., 2018 } \\
\text { [25] }\end{array}$ & Hungary & urban & $\begin{array}{l}\text { In Debrecen city, with moderate } \\
\text { traffic, far from industrial } \\
\text { pollution. }\end{array}$ \\
\hline $\begin{array}{l}\text { Choudhury \& Banerjee } \\
\text { 2009 [8] }\end{array}$ & India & industrial & $\begin{array}{l}\text { In an industrial belt with a large } \\
\text { variety of industries present. }\end{array}$ \\
\hline $\begin{array}{l}\text { Gupta et al. 2016 } \\
{[16]}\end{array}$ & India & industrial & $\begin{array}{l}\text { In the industrial area of } \\
\text { Sahibabad. }\end{array}$ \\
\hline $\begin{array}{l}\text { Acharya et al. 2017 } \\
{[15]}\end{array}$ & India & roadside & $\begin{array}{l}\text { In an area adjacent to the National } \\
\text { Highway 5. }\end{array}$ \\
\hline $\begin{array}{l}\text { Rai \& Panda 2013 } \\
\text { [21] }\end{array}$ & India & roadside & $\begin{array}{l}\text { Along the roadside in polluted } \\
\text { areas. }\end{array}$ \\
\hline $\begin{array}{l}\text { Pathak et al. 2011 } \\
{[20]}\end{array}$ & India & urban & $\begin{array}{l}\text { In Varanasi, on the banks of the } \\
\text { Ganges. }\end{array}$ \\
\hline $\begin{array}{l}\text { Sulistijorini et al. 2008 } \\
{[23]}\end{array}$ & Indonesia & roadside & $\begin{array}{l}\text { Along a highway with high traffic } \\
\text { volume. }\end{array}$ \\
\hline $\begin{array}{l}\text { Gholami et al. 2016 } \\
{[12]}\end{array}$ & Iran & urban & $\begin{array}{l}\text { In Ahvaz, one of the most polluted } \\
\text { cities in the world. }\end{array}$ \\
\hline $\begin{array}{l}\text { Ogunkunle et al. 2015 } \\
\text { [24] }\end{array}$ & Nigeria & urban & $\begin{array}{l}\text { On the perimeter of the campus of } \\
\text { University of Ilorin }\end{array}$ \\
\hline
\end{tabular}

2.2 Study area and sample collection

We selected the C. occidentalis and Tilia sp. to test the usefulness of APTI in Hungary. The studied species' leaves were collected in Debrecen city, similarly to earlier studies [25]-[27]. The average particulate matter concentration $\left(\mathrm{PM}_{10}\right)$ in the city ranged between 27-40 $\mu \mathrm{g} \mathrm{m}^{-3}$ between 2005-2017 [28]. The sample collection was executed on the same day in the autumn of 2017, when 12 sampling points were chosen evenly across the city. Tree leaves were collected in paper bags from individuals of Celtis occidentalis and Tilia sp. from a height of $1-1.5 \mathrm{~m}$ above the ground.

\subsection{Sample preparation}

Chlorophyll content was extracted from approximately $20 \mathrm{mg}$ leaf tissue with $5 \mathrm{ml} \mathrm{96 \%}$ ethanol. The total chlorophyll content (TChl) was measured through spectrophotometric analysis and it was calculated from the following equation, expressed in $\mathrm{mg} \mathrm{g}^{-1}$ fresh weight

$$
\operatorname{TChl}\left(m g g^{-1}\right)=\left(17.12 \times E_{666}-8.68 \times E_{653}\right) \times \frac{V}{m} \times 1000
$$

$\mathrm{E}_{666}$ and $\mathrm{E}_{653}$ are the absorbance at $666 \mathrm{~nm}$ and $653 \mathrm{~nm}$ minus the absorbance at $750 \mathrm{~nm}$, respectively, $V$ is volume $(\mathrm{ml})$ of leaf extract and $m$ is the fresh weight $(\mathrm{g})$ of leaf sample. 
Relative water content (RWC) was measured using the following parameters: the fresh weight of leaves (FW), the turgid weight (TW) that was recorded after the leaves were immersed in water overnight, and finally the dry weight of the leaves (DW) after letting them dry in an oven at $70^{\circ} \mathrm{C}$. RWC was calculated from the following formula:

$$
R W C(\%)=\frac{F W-D W}{T W-D W} \times 100 .
$$

The acidity of the leaf extract was measured by a digital $\mathrm{pH}$ meter.

The ascorbic acid content was measured by titration method. $2 \mathrm{~g}$ of leaf was crushed and homogenized in deionised water, then after filtration the samples were titrated using iodine solution and starch indicator. Ascorbic acid content was expressed in $\mathrm{mg} \mathrm{g}^{-1}$. APTI of species was determined by using the following formula:

$$
A P T I=\frac{A(T+P)+R}{10},
$$

where $A$ is the ascorbic acid content, $T$ is the total chlorophyll content, $P$ is the leaf extract $\mathrm{pH}$ and $R$ is the relative water content.

According to the categorization introduced by Singh et al. [29], a tree species is regarded to be sensitive when the index value is 14 or less. The APTI value of an intermediate and moderately tolerant species range from 15 to 19 , and 20 to 24 , respectively. The APTI values of a tolerant species is above 24 .

\subsection{Statistical analysis}

Statistical calculations were performed by the SPSS/PC+ statistical software package. We tested the variables for normal distribution with the Shapiro-Wilk test. The homogeneity of variances was tested with Levene's test. Analysis of variance (ANOVA) in General Linear Models (GLM) module was used to compare APTI values among countries and study area types.

\section{RESULTS AND DISCUSSION}

\subsection{Comparison of APTI among countries}

We compared several countries based on the APTI values in the selected studies. The highest APTI values were in China: it was significantly higher than in Hungary $(p<0.001)$, India $(p<0.05)$, Iran $(p<0.001)$ and Nigeria $(p<0.001)$. APTI in India was ranked as second one, and it was significantly higher than in Hungary $(\mathrm{p}<0.05)$ and Iran $(\mathrm{p}<0.001)$ (Fig. 1). Basically, China and India were the most polluted countries among the studied countries, and they had plant species with relatively high APTI. This means that in these regions environmental conditions are mainly suitable for tolerant species. The higher level of pollution may be the cause of higher tolerance level of native species which is a plain defence mechanism. There is already a growing interest in the application of plants to reduce air pollution in India, which explains the high amount of studies in the country. India is a quickly developing country, and it has undergone intense industrialization and urbanization in the last decades [7], which caused a rapid increase in pollution levels. 


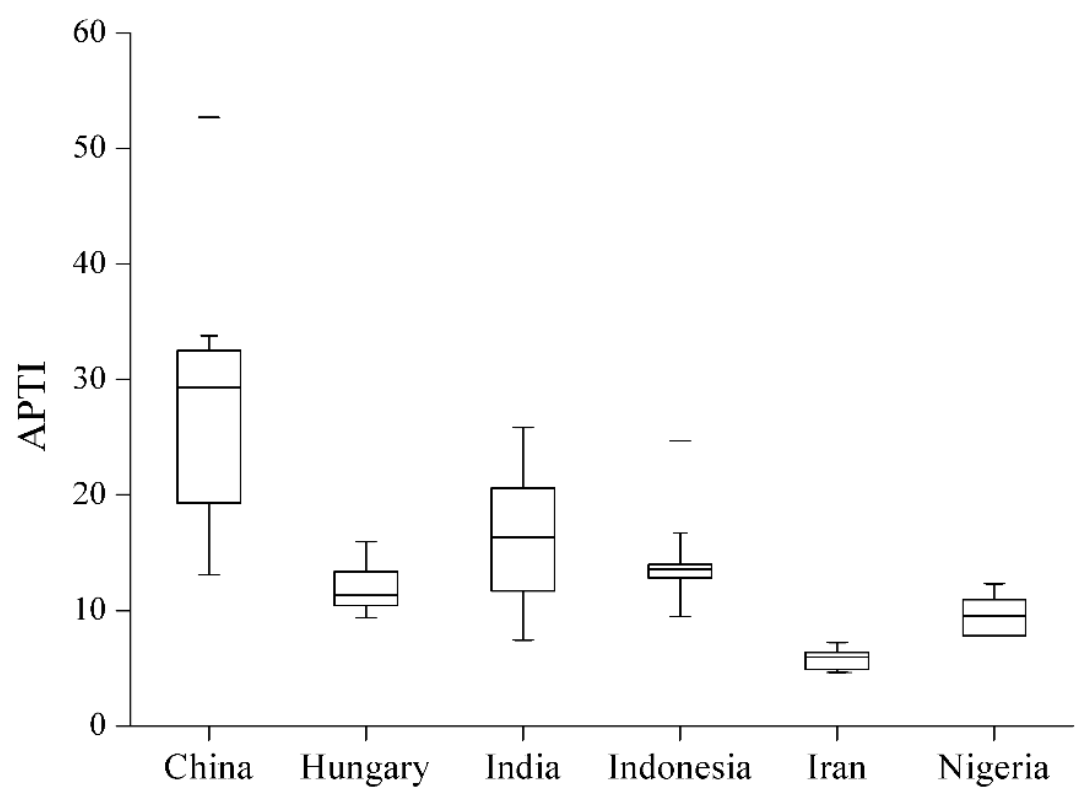

Figure 1: Reported APTI values in the studied countries.

Among the selected studies, tree species with the lowest average APTI were found in Ahvaz, Iran. Ahvaz was ranked as the world's most air-polluted city by the World Health Organization in 2013 [12]. The climate in this region is hot and humid, and there is an abundance of dust. Based on APTI, tree species had rather low tolerance against pollution. This shows that at extremely polluted sites, air pollutants can degrade biochemical parameters (such as chlorophyll or ascorbic acid content) of plants to a degree that they become overly sensitive against air pollution. APTI determined by us in Hungary was moderate compared to the APTI values of other countries. It was significantly lower than in China $(\mathrm{p}<0.001)$ and India $(\mathrm{p}<0.05)$, where the most tolerant species were present.

\subsection{Comparing APTI among study areas}

We identified three types of area: industrial area, roadsides, and urban area. Highest average APTI was found at industrial sites, which differed significantly from the roadsides $(p<0.05)$ and the urban areas $(p<0.001$; Fig. 2$)$. APTI values at roadsides were significantly higher than in urban areas $(\mathrm{p}<0.05)$. Accordingly, the tolerance of plant species decreased in the following order: industrial $>$ roadside $>$ urban areas. Thus, presumably, the level of overall pollution revealed the same trend: it was the highest at industrial sites and the lowest in urban areas. This suggests the best conditions for development and growth of sensitive species in urban areas, while the presence of industrial activities in certain areas demands higher tolerance from plants.

Result of APTI corresponds with other researches that studied urban areas [20], [24]. Debrecen is far from any direct industrial emission, and the air quality is mainly determined by the local pollution sources that are specific to urban areas such as vehicular traffic, households [27], and it is reflected in the APTI values. 


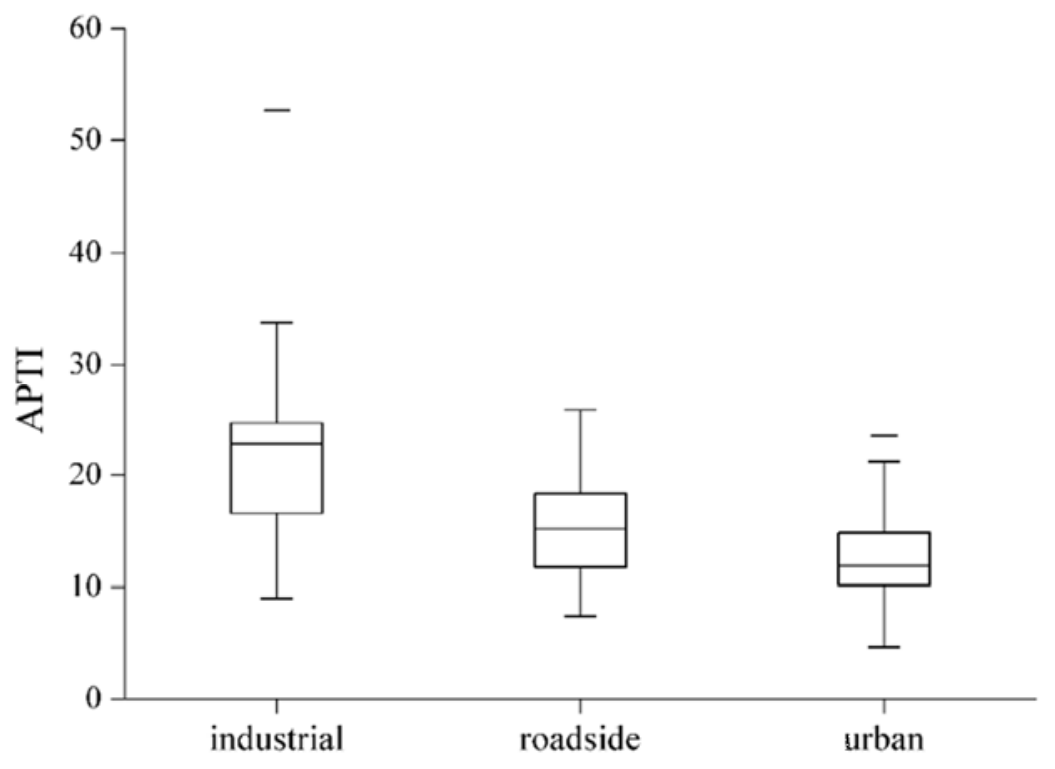

Figure 2: Boxplots of APTI values by study areas.

\section{CONCLUSIONS}

Air pollution is presently a severe environmental problem in many countries. It has a large impact on vegetation near emission sources. Evaluation of Air Pollution Tolerance Index (APTI) can be used to find suitable plant species for reduction of pollutants and to identify possible indicators of such pollutants. We collected studies reporting APTI values from several countries and compared their findings with our data from Hungary. The comparison revealed that the most tolerant species were present in highly polluted countries, in China and India. Our results in Hungary significantly differed from the above countries, suggesting better conditions for sensitive species. Values of APTI was also compared among industrial, roadside and urban areas. Literature review suggests that industrial emissions have a profound impact on sensitivity of plants, as such polluted areas were mostly suitable for species with high tolerance. Based on the results of our study we recommend to plant tree species that are tolerant to air pollution in polluted countries, especially near direct emission sources. Meanwhile in urban areas, where the environment also favours sensitive species, such plants should be planted and used to indicate changes in air quality. Based on our findings, the species studied in Hungary were classified as sensitive, thus these species are useful species as bioindicators of air pollution.

\section{ACKNOWLEDGEMENTS}

The publication is supported by the EFOP-3.6.1-16-2016-00022 project. The project is cofinanced by the European Union and the European Social Fund. Research was supported by OTKA K 116639, KH 126481 and KH 126477 grants.

\section{REFERENCES}

[1] Grigoratos, T. \& Martini, G., Non-exhaust traffic related emissions. Brake and tyre wear PM, Publications Office of the European Union: Luxembourg, p. 53, 2014. 
[2] Agbaire, P.O \& Akporhonor, E.E., The effects of air pollution on plants around the vicinity of the Delta Steel Company, Ovwian-Aladja, Delta State, Nigeria. IOSR Journal of Environmental Science, Toxicology and Food Technology, 8(7), pp. 61-65, 2014.

[3] Chauhan, A. \& Joshi, P.C., Effect of ambient air pollutants on wheat and mustard crops growing in the vicinity of urban and industrial areas. New York Science Journal, 3(2), pp. 52-60, 2010.

[4] Chaurasia, S., Karwariya, A. \& Gupta, A.D., Effect of cement industry pollution on chlorophyll content of some crops at Kodinar, Gujarat, India. Proceedings of the International Academy of Ecology and Environmental Sciences, 3(4), pp. 288-295, 2013.

[5] Hanesch, M., Scholger, R. \& Rey, D., Mapping dust distribution around an industrial site by measuring magnetic parameters of tree leaves. Atmospheric Environment, 37, pp. 5125-5133, 2003.

[6] Kaur, M. \& Nagpal, A.K., Evaluation of air pollution tolerance index and anticipated performance index of plants and their application in development of green space along the urban areas. Environmental Science and Pollution Research, 24(23), pp. 1888118895, 2017.

[7] Hariram, M., Sahu, R. \& Elumalai, S.P., Impact assessment of atmospheric dust on foliage pigments and pollution resistances of plants grown nearby coal based thermal power plants. Archives of Environmental Contamination and Toxicology, 74(1), pp. 56-70, 2018.

[8] Choudhury, P. \& Banerjee, D., Biomonitoring of air quality in the industrial town of Asansol using the Air Pollution Tolerance Index approach. Research Journal of Chemistry and Environment, 13(1), pp. 46-51, 2009.

[9] Joshi, P.C. \& Swami, A., Physiological responses of some tree species under roadside automobile pollution stress around city of Haridwar, India. Environmentalist, 27, pp. 365-374, 2007.

[10] Girish, L., Krishnankutty, K. \& Vaidya, S., Air pollution tolerance index of selected plants growing near road side of Navi Mumbai, Maharashtra. International Journal of Current Research, 9(9), pp. 57807-57811, 2017.

[11] Zhang, P., Liu, Y., Chen, X., Yang, Z., Zhu, M. \& Li, Y., Pollution resistance assessment of existing landscape plants on Beijing streets based on air pollution tolerance index method. Ecotoxicology and Environmental Safety, 132, pp. 212-223, 2016.

[12] Gholami, A., Mojiri, A. \& Amini H., Investigation of the air pollution tolerance index (APTI) using some plant species in Ahvaz region. The Journal of Animal \& Plant Sciences, 26(2), pp. 475-480, 2016.

[13] Otuu, F.C., Inya-Agha, S.I., Ani, U.G., Ude, C.M., \& Inya-Agha, T.O., Air Pollution Tolerance Indices (APTI) of six ornamental plants commonly marketed at "Ebano Tunnel" floral market, in Enugu Urban, Enugu State, Nigeria. IOSR Journal of Environmental Science, Toxicology and Food Technology, 8(1), pp. 51-55, 2014.

[14] Pandey A.K., Pandey, M. \& Tripathi, B.D., Air Pollution Tolerance Index of climber plant species to develop Vertical Greenery Systems in a polluted tropical city. Landscape and Urban Planning, 144, pp. 119-127.

[15] Acharya, S., Jena, R.C., Das, S.J., Pradhan, C. \& Chand, P.K., Assessment of air pollution tolerance index of some selected roadside plants of Bhubaneswar city of Odisha State in India. Journal of Environmental Biology, 38, pp. 1397-1403. 
[16] Gupta, G.P., Kumar, B. \& Kulshrestha, U.C., Impact and pollution indices of urban dust on selected plant species for green belt development: mitigation of the air pollution in NCR Delhi, India. Arabian Journal of Geosciences, 9(136), 2016.

[17] Lohe, R.N., Tyagi, B., Singh, V., Kumar Tyagi, P., Khanna, D.R. \& Bhutiani, R., A comparative study for air pollution tolerance index of some terrestrial plant species. Global Journal of Environment Science and Management, 1(4), pp. 315-324, 2015.

[18] Madan, S. \& Verma, P., Assessment of air pollution tolerance index of some trees in Haridwar City, Uttarakhand. Journal of Environmental Biology, 36, pp. 645-648, 2015.

[19] Mahecha, G.S., Bamniya, B.R., Nair, N. \& Saini, D., Air pollution tolerance index of certain plant species: A study of Madri industrial area, Udaipur (Raj.), India. International Journal of Innovative Research in Science, Engineering and Technology, 2(12), pp. 7927-7929, 2013.

[20] Pathak, V., Tripathi, B.D. \& Mishra, V.K., Evaluation of Anticipated Performance Index of some tree species for green belt development to mitigate traffic generated noise. Urban Forestry \& Urban Greening, 10, pp. 61-66, 2011.

[21] Rai, P.K. \& Panda, L.L.S., Dust capturing potential and air pollution tolerance index (APTI) of some road side tree vegetation in Aizawl, Mizoram, India: an Indo-Burma hot spot region. Air Quality, Atmosphere \& Health, 7(1), pp. 93-101, 2014.

[22] Liu, Y. \& Ding, H., Variation in air pollution tolerance index of plants near a steel factory: Implications for landscape-plant species selection for industrial areas. WSEAS Transactions on Environment and Development, 4(1), pp. 24-32, 2008.

[23] Sulistijorini, Mas'ud, Z.A., Nasrullah, N., Bey, A. \& Tjitrosemito, S., Tolerance levels of roadside trees to air pollutants based on relative growth rate and air pollution tolerance index. HAYATI Journal of Biosciences, 15(3), pp. 123-129, 2008.

[24] Ogunkunle, C.O., Suleiman, L.B., Oyedeji, S., Awotoye, O.O. \& Fatoba, P.O., Assessing the air pollution tolerance index and anticipated performance index of some tree species for biomonitoring environmental health. Agroforestry Systems, 89, pp. 447-454, 2015.

[25] Molnár, V.É., Tóthmérész, B., Szabó, Sz. \& Simon, E., Urban tree leaves’ chlorophylla content as a proxy of urbanization. Air Quality, Atmosphere \& Health, 2018. DOI: 10.1007/s11869-018-0573-5.

[26] Simon, E., Braun, M., Vidic, A., Bogyó, D., Fábián, I. \& Tóthmérész, B., Air pollution assessment based on elemental concentration of leaves tissue and foliage dust along an urbanization gradient in Vienna. Environmental Pollution, 159, pp. 1229-1233, 2011.

[27] Simon, E., Baranyai, E., Braun, M., Cserháti, C., Fábián, I. \& Tóthmérész, B., Elemental concentrations in deposited dust on leaves along an urbanization gradient. Science of the Total Environment, 490, pp. 514-520, 2014.

[28] Hungarian Air Quality Network, Reports of the automatic network 2005-2017. http://levegominoseg.hu/ertekelesek. Accessed on: 4 Jan. 2018.

[29] Singh, S.K., Rao, D.N., Agrawal, M., Pandey, J. \& Narayan, D., Air Pollution tolerance index of plants. Journal of Environmental Management, 32, pp. 45-55, 1991. 